\title{
The Social Agency of Things? Animism and Materiality in the Andes
}

\author{
Bill Sillar
}

\begin{abstract}
A major focus of inter-disciplinary debate has been the need to bridge the Cartesian divide between people as active subjects and inert passive objects, to better reflect how things provoke and resist human actions through their 'secondary agency'. Many Central Andean people express a deep concern about their relationship with places and things, which they communicate with through daily work and rituals involving 'sympathetic magic'. A consideration of Andean animism emphasizes how agency is located in the social relationship people have with the material world and how material objects can have social identities.
\end{abstract}

The close bond that exists between people and things is well illustrated in our use of the motor car. As drivers we can treat the car as an extension of our bodies changing gear with minimal conscious effort, yet we can also treat it as a willful living entity, venting our anger at cars that 'refuse' to start (Gell 1998). Similarly we may shout at the computer that deletes our files, or fondle the keep-sake that reminds us of a departed friend. Are these actions provoked by our minds and the ideas we project onto things? Are they inherent within the materiality and actions of the object? Or, is agency a quality of the relationship between people and objects that cannot adequately be located in either of them separately? I consider the last of these options a more fruitful route for discussion and, because this 'relational' view is fundamental to the practices that Tylor (1923) categorized as animism, a consideration of animistic world-views may assist this discussion.

I start this article with a review of work on agency and materiality which outlines my own view of human and material agency. In the next section I review animism in the Central Andes in relation to historical and archaeological work relating to the Inca state and recent ethnographic research by myself and others. The aim is to show how Andean people construct social relationships with the material world, how this relational view gives identity to things, and how offerings and daily work are used to develop reciprocal social obligations with these animate objects and places. Through this discussion I seek to draw out issues that are central to the practice of Andean animism that are also of concern within current theories of agency and materiality. For instance, I will show how objects that have had a prior relationship with other places, things or people are thought to remain in communication even after their physical separation, some Andean people use this 'inalienable' character of things to construct offerings that draw places, things and people into reciprocal obligations. This provides a different perspective on Gell's discussion of 'secondary agency' which has a very direct bearing on how we should interpret the selection and composition of 'ritual deposits' in archaeology.

\section{The agency of people and things}

Human agency is usually located in both the capacity of people to develop 'aims' and the actions they undertake to try to achieve those aims (Dobres \& Robb 2000). Human agency is the ability to both imagine and enact different actions while continually re-evaluating the efficacy of these actions within changing situations (Emirbayer \& Mische 1998). A person's agency requires self-awareness and volition, but it is socially embedded and constrained within wide-ranging economic and social structures. One of the primary outcomes of our individual agency is to reproduce these structures, often as the unintended outcome of our actions (Bourdieu 1977; Giddens 
1984). Human agency is not the ability to achieve specified aims, a definition that may better describe a computer or machine, it is rather the motivation and individual creativity incorporated in the human body through which we gain the physical ability to act and engage in social relations. Gardner usefully defines agency as an active human involvement in the world

both as a capacity or quality of being human and as a process or relationship of engagement with a social and material world. This means that there is no agency without individual humans, who have a distinctively active, embodied consciousness, but that equally there can be no autonomous agent, as this active consciousness can only really develop through interaction (fundamentally binding agency to structure) (Gardner 2007, 103 - emphasis in original).

If we are to identify what makes human agency different to that of other animals, we need to consider how human self-conscious cognitive abilities developed. Many of the cognitive abilities that we consider central to our self-consciousness could only have developed through our ancestor's engagement with material culture (Mithen 2001; Renfrew 2004). Mead (1934; 1938) argued that our self-consciousness emerges out of the dynamic process of our interaction with physical objects including our own and other people's physical bodies. A fundamental corollary of this 'self-perception' is the capacity to conceptualize the perspective of another person. This is what Mead calls our capacity for sociality, the ability to 'take the attitude of the other' (Mead 1932, 87). Mead uses the term sociality in a broad sense to describe the process through which two or more entities went through a 'contact experience' which influenced the physical entities involved (such as the relationship between planets). But here I am referring to Mead's (1932) concept of the more developed sense of sociality which allows humans to remember past actions and anticipate future responses, and to imagine how different participants may interpret and respond to the situation. Sociality provides us with the ability to empathize with other human beings by using our imagination to 'take the attitude' of another individual or the 'generalized other' of a social group (Mead 1932, 87). But it can also involve the attribution of human-like personalities and desires to animals, plants, places and things. Mead suggested that 'primitive man keeps en rapport with implements and weapons by conversations in the form of magic rites and ceremonies' (Mead 1932, 169), and considered the delimitation of objects as purely physical or mechanical things lacking in social or living characteristics to be a further stage of mental development. Yet what characterizes animistic beliefs is precisely an empathetic concern for places and things which are considered to have social identities (although not always 'human-like').

Most researchers make a clear distinction between the agency of people and materials as physical resources; however the degree to which people (such as slaves and factory workers) or things (such as mountains and paintings) are attributed social identities, and considered to have the power to act depends on cultural perceptions, and this affects what constitutes 'social relations'. Things engage our emotions and evoke memories, ideas and meanings in our minds giving them a 'social life' (MerleauPonty 2002; Appadurai 1986; Jones 2007), and the 'inalienable' character of some things allows them to carry some of the identity of the maker or previous owners (Weiner 1992). Robb (2004) has discussed the idea of the 'extended artefact', highlighting the complex web of interdependent relationships that many things embed us in, providing much of the structure of society and the tools for human agency. All of this gives artefacts 'secondary agency' (Gell 1998), even if an artwork lacks volition or intentionality it can have an effect on other people that is independent of the original maker's intentions. While most of these authors discuss how things have some power or capacity to elicit human emotions and influence our actions, a few introduce the possibility that things actually have a degree of intentionality of their own. Latour's (1993) symmetrical anthropology has challenged our prioritizing of human agency by exploring causal agency from the viewpoint of material objects as well as human 'subjects'. Gell (1998) and Gosden (2005) both explore the possibility that artefacts with particular forms and designs use people as a medium for their own reproduction. Gardner $(2007,103)$ points out that these stronger claims for the active agency of things could have the dangerous effect of undermining individual human responsibilities and rights (e.g. blaming the Columbine student massacre on guns or video games: Strauss 2007). The material world is not passive, as it both provokes and resists human actions, however I agree with Robb (2004) that the degree to which things have a 'secondary' or 'effective' agency originates in how people perceive and engage with things through their conscious agency. Below, I will discuss how Andean concepts of animism are a potential challenge to this view as they consider places and things to be sentient entities that have the power to act. 


\section{Animism}

A social relationship with the material world

Tylor (1913) defined animism as the belief that an entity has a soul or animating spirit. Many people consider some or all ancestors, animals, plants, places and things to have a vital force, spirit or identity that directly affects the human world, and that these non-human 'persons' deserve respectful relationships from humans (Harvey 2005). Tylor's work can be criticized for the underlying assumptions of progressive social evolution, and one of the fall-outs from this has been the frequent stress on examples of animism as a 'primitive' aspect of hunter-gatherer societies. However, animism is a wide-spread ontology that is maintained within a wide range of social structures, economies, beliefs and world-views. The idea that a 'spirit' was needed to account for 'primitive' beliefs in animate objects was in part due to the projection of Tylor's Christian concepts. Marett (1914) criticized Tylor for assuming that the attribution of life-like properties to things requires a belief in souls, and he adopted the Melanesian word mana to describe this vitalizing force. Recent discussions of animism have continued to critique the focus on the 'spirit' or 'soul' as somehow beyond nature or the experienced aspects of the physical world (Ingold 2006). A large part of what Tylor was describing as animism is a very direct and personal engagement with the materiality of the natural and cultural world, what is distinct is the assumption that some or all aspects of the material world are sentient and can be communicated with in a direct and social way. This led Bird-David (1999) to adopt the term 'relational epistemology' to describe the core values of animism as a belief in the ability of people, places and things to communicate with each other rather than Tylor's focus on the super-natural world of spirits (Ingold 2006; Hornborg 2006).

Today, in the Central Andean highlands of Peru and Bolivia, the focus of animism is most clearly expressed in relation to prominent mountains (Apus), agricultural fields (Pachamama), the house, the recently dead and miraculous saints (Bastien 1978; Allen 1988; Gose 1994). These entities have a power, or sphere of influence, that extends beyond their physical location: the ancestors and pachamama influence the growth of crops, the mountains have a wide ranging influence, including control over camelid herds and mining activities, and the saints teach people craft skills, provide security during travel and promote good health (Allen 1988; Gose 1994; Sallnow 1987). The mountains and saints can offer benevolent productivity to those who engage in appropriate reciprocity, or become malevolent and potentially violent to those who are careless, exploitative or immoral. Many Andean people today commit time, thought and materials to making various offerings in order to supplicate these entities. Almost all ritual activity is focused on justifying interventions such as ploughing, mining and travelling as well as requesting well-being and productivity. This is achieved through developing a personal relationship with specific animate places through repeated offerings, annual pilgrimage, and frequent evocation. The 'success' of sacrifice is not measured in any visible response or change but is considered an essential part of the continuity of daily life. In fact it is a mistake to separate such ritual offering from other activities such as agricultural work, animal husbandry, music and dance are also considered to be acts of communication and exchange with the animate forces of pachamama and the apus (Gose 1986; Laurencich-Minelli 1991; Stobart 2006).

Highland Andean people do not use terms such as 'god' or 'super-natural' to describe the animate world which is usually considered to be immediate and tangible. Although ethnographers have used terms such as 'mountain deities', the sentient mountains are usually equated with powerful people (such as Pre-Columbian ethnic leaders - apus) that 'commoners' try to supplicate and occasionally remonstrate against.

The Andean people do not separate the natural from the spiritual environment. They believe that, like animals and people, all elements of nature live, feel, and breathe. Pachamama, the Apus, lakes, rocks, springs, and animate and inanimate beings - all aspects of nature need food and drink, love and consideration (Bolin 1998, 43).

While I have only been told that people have a soul 'alma', both people and other entities (e.g. alpacas, maize, illas) can have 'ánimo', the vitalizing energy that animates life (cf. Allen 1982; 1988, 60-62; Gose 1994, 115-16; Stobart 2006, 27-8) It is interesting to note that when the people of Huaquirca, Apurimac, Peru, report to Peter Gose seeing the almas separated from the ánimo of dying people they could be recognized by

their inability to perceive or interact with the living. Deafness to the greetings of the living is the most common way these almas are detected as such. Since the ánimo is supposed to maintain the senses, it is logical that these almas wandering in a state of separation would be oblivious to the presence of others (Gose 1994, 116; cf. Stobart 2006, 28; Allen n.d.).

It is the ánimo, the vitalizing animation which people, animals and some things possess, which provides the activity and senses vital to perception and communication, not the human soul. 
In his long, illustrated letter to the king of Spain, the native author Guaman Poma (1988) depicts the Inka period huacas (cult objects and locations that were the focus of veneration) with eyes and mouths. Although wooden and stone carvings were made and worshipped before the Spanish conquest this form of anthropomorphizing is not a feature of current Andean animism. It seems likely that in order to communicate the idea of the animate world to the Spanish, Guaman Poma felt the need for some illustrative convention to depict the animate entities, whereas native Andeans did not require the addition of facial features to perceive the material world as living. The material world can be conceived of as sentient without the need to impute purely human-like qualities or 'spirit' to it. For instance, the huaca of Huanacaure, one of the most important huacas of the Inca state, was overlooked by the Spanish when sacking its cult site, because they only saw a 'rough stone' (Cobo 1990, 74). Yet this 'rough stone' was considered to be the petrified body of Ayar Cache, a founding ancestor of the Inka lineage. The fact that material objects and places could be drawn into human kinship shows how the boundary between human, place and thing were much less clear in the Andes of the fifteenth century than Cartesian views would allow (Bray, this issue). Although the animate power of the material world is also a feature of modern Andean beliefs there have been significant changes since 1532 .

Gose (2006) has drawn attention to the fact that the earliest Spanish records suggest that many huacas were specific objects, but mountains and large-scale landscape features became a more dominant focus of Andean animism after the Spanish extirpation of idolatries. While Inka rituals frequently focused around specific objects, such as the Huanacaure stone huaca, they also focused on wider landscape, as can be seen in the high mountain Capacocha sacrifices (see below). Since the Spanish priests put great effort into finding and destroying the material focus of any native Andean rituals such as huacas and mummy bundles, broad, indestructible, landscape features have gained ever greater strength. While in the colonial period, saints' effigies joined the hierarchy of Andean animate beings, and more recently trucks and computers have joined houses and animal herds as a focus for protective rituals. Thus, the focus of animism is not fixed, but is continually developing within the social history of the area.

Mutual consumption - feed the world

Today Andean animism is most clearly expressed within a series of practices through which people make offerings that seek to reciprocate the benevolence of the animate world, or stave off malevolence. A central purpose of these rituals is to engender and promote a commitment on the part of the mountains, ancestors and other animate forces to the people making the offerings. This relational view of animate non-human entities is embedded within a moral conception of society (cf. Descola 1994). Andean concerns about appropriate reciprocity are described both in relation to people and in terms of ritual obligations to the saints and apus (Isbell 1985). As with all gifts, the aim of ritual offerings is to create a tie of obligation between the animate entity and the devotee making the offering (Mauss 1990; Sillar 2004), these gifts are a material expression of an on-going commitment to care for the house, the fields and the animals that is also expressed in less overtly ritual acts such as ploughing, irrigating and planting crops.

A major expression of the social relationship between people and things is the fact that people are responsible for feeding the mountain (apus), mother earth (pachamama), miraculous saints and other entities. This is a form of 'mutual consumption' as it is only if people give nourishment to the animate world that they can expect to be fed in return (Isbell 1985; Weismantel 1988; Gose 1994; Sillar 2000). This feeding takes place through feasts and offerings that bind the household and/or the community to each other and to the focus of their sacrificial acts (Isbell 1985; Abercrombie 1998; Gose 1986; Allen 1988).

In the Andean highlands today such offerings may be 'sent' through four major routes (cf. Allen 1982, 191):

1. Food offerings can be sent through the body of a participant who consumes food and drink for the stated recipient (e.g. a living person or ancestor).

2. A small amount of drink can be poured or the essential essence (sami) of coca leaves can be blown towards a named recipient such as a house, mountain apu or saint.

3. A prepared offering can be burnt in a fire (referred to as a dispachu from the Spanish term for a message).

4. An offering can be buried or placed at a specific location (e.g. when constructing a house).

Each of these methods combines the preparation of particular goods and directing their life-giving force through the location, orientation and composition of the offering as well as a verbal evocation of the recipient. Similar techniques are also reported for the Inka (Cobo 1990, 115-17).

Drinks such as maize beer and alcohol provide a major route for communication with the dead, but 
may also be directed at other entities such as the mountain apus and saints (Abercrombie 1998). Prior to drinking, a small libation (ch'alla) is poured on the ground or a little of the chicha is flicked into the air ( $t^{\prime}$ inka) with pachamama an apu, saint, ancestor or animate entity being stipulated as the recipient of the essence of the drink (sami) (Allen 1988) (Fig. 1). Although most modern domestic pottery in the Andes is not highly decorated, the most complex pottery forms and elaborate decoration are applied to vessels used in the preparation and particularly the consumption of chicha (Sillar 2000). This preference for decorating drinking cups is partly because chicha-drinking is a communal activity, but it is also because chicha is used as a form of communication with the ancestors and animate world. The form and decoration of the drinking vessels

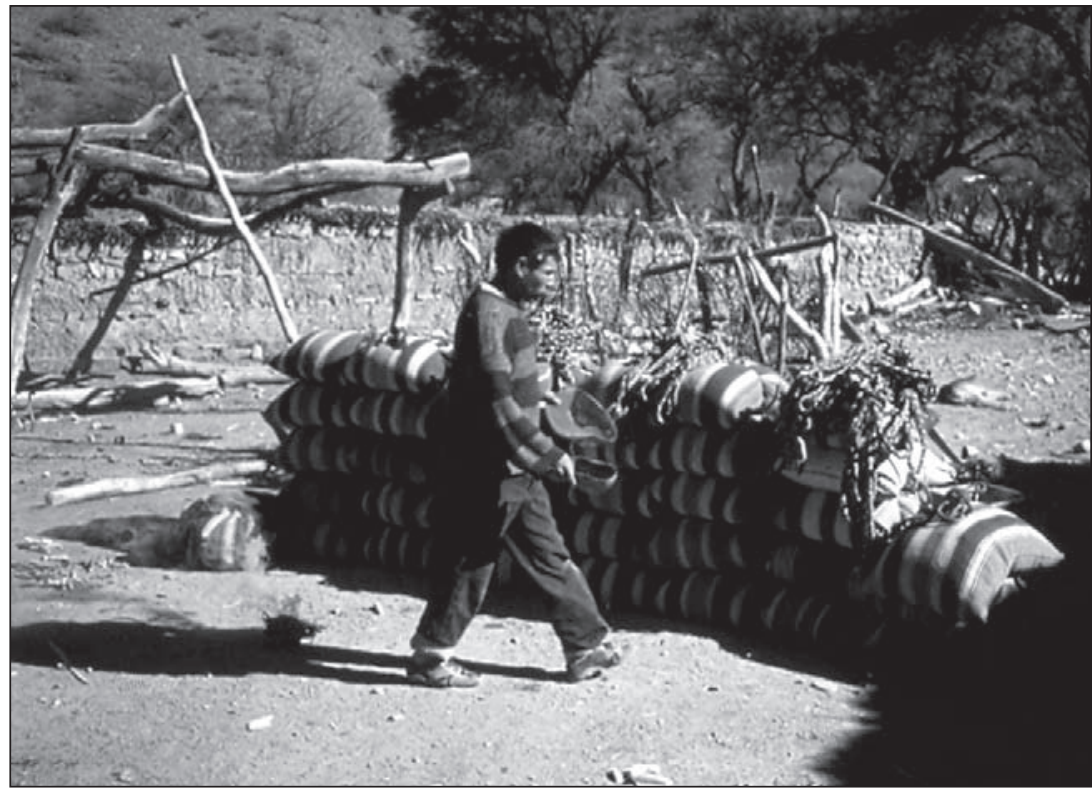

Figure 1. Itinerant potter from Ticatica, Potosi, Bolivia with 34 sacks of maize acquired in exchange for the pottery he made. Before his return home he is making a burnt offering (smoking to the left) and libations of chicha (from the gourd in the potter's hand) for the maize and his safe journey. express ideological concepts such as animal fecundity and balanced complementarity (Stobart 1996) and these symbolic messages are directed not just at other people but at the animate world to whom the chicha offerings are made (cf. Sterner 1989) (Fig. 2).

Sympathetic magic: the inalienable connectedness of things In Raqchi, Department of Cuzco, Peru, an offering is made by most households on the night of San Luis (24 August) when family members chew coca, and make libations over a ritual cloth. Next to this cloth are placed the illas, carved figures or natural pebbles that evoke animals, houses, or crop plants (Fig. 3). These illas are living beings said to be found on the hillside that come as gifts (indeed as the children) of the mountain deities (apus) (Flores-Ochoa 1979; Isbell

Figure 2. (on right) Drinking chicha and making libations (ch'alla) during Todos Santos, Pumpuri, Potosi, Bolivia. The turuwasus the men are drinking out of are wooden bowls with carved plough teams in the middle, at other times of the year each individual drinker holds both of the paired vessels for ritual drinking, but during Todos Santos, when participants are drinking with the dead, the turuwasus are used singly. At their feet is a wich'i being used to serve chicha, and two pottery llamas (samiri) also used for ritual drinking and libations.

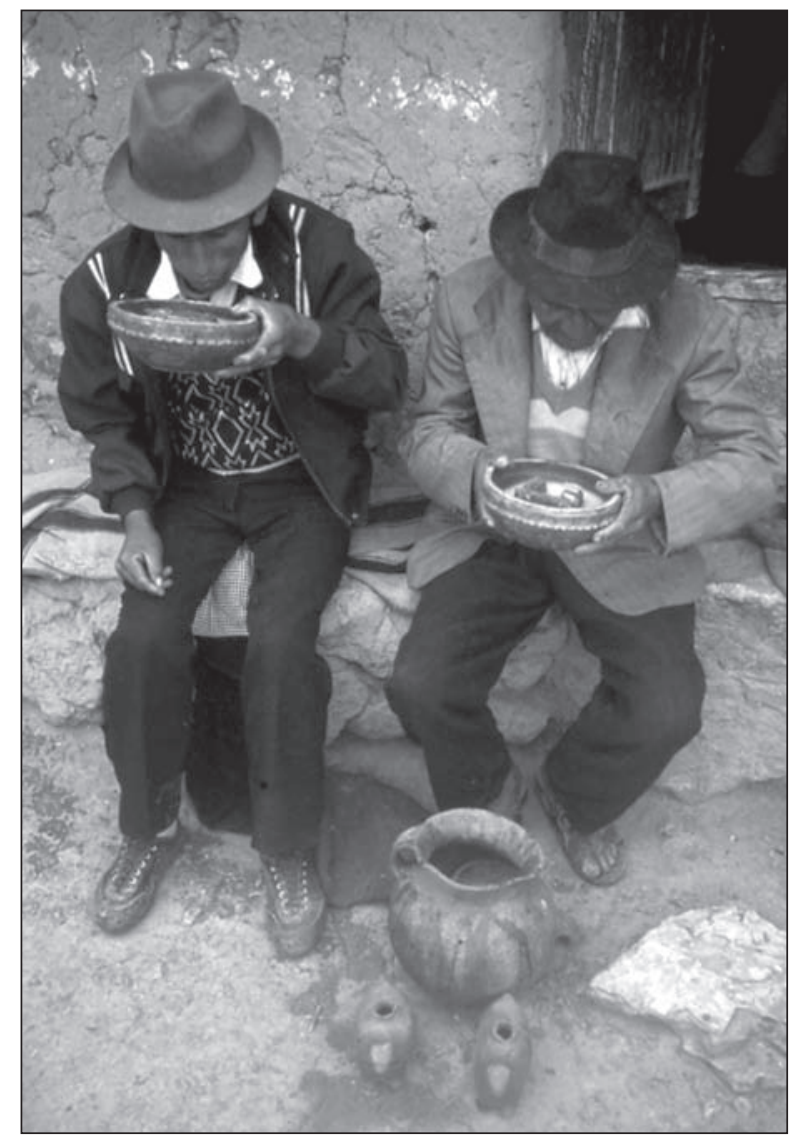




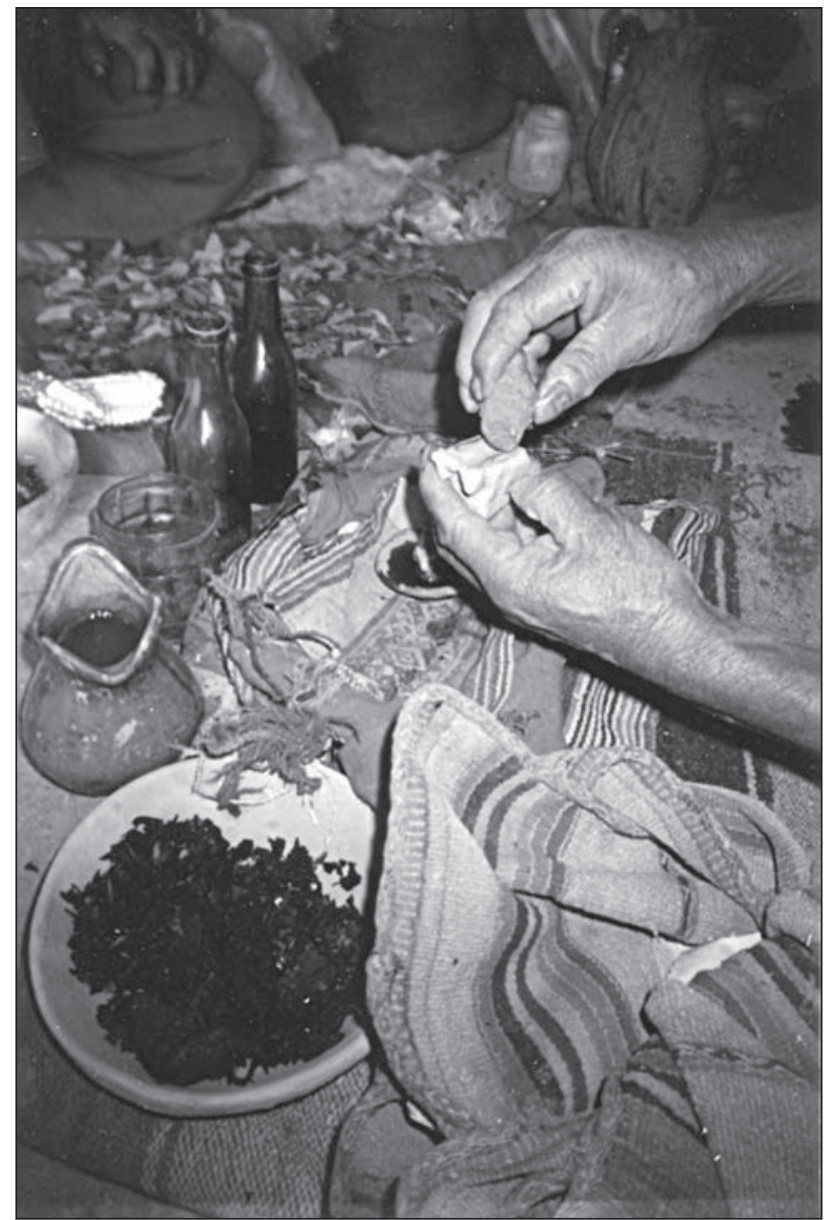

Figure 3. Raqchi, Dept. Cuzco, Peru. At the start of preparing the second $\mathrm{k}$ 'intuqwi offering, which gives thanks for, and requests the, health and fertility of the household's animals. The carved stone illa of a plough team is marked using the same hematite-rich clay used to mark sheep and llamas and to paint pottery. The bowl of coca leaves chewed during the preparation of the offerings, the content of the small bottles of alcohol and wine, and the little jug of chicha will all be included in the burnt offering (dispachu). At the centre of the photograph, behind the father's hands a small bowl (referred to as a cocha or lake, evoking the place from which the animals are thought to have originated) is filled with wine which the small illa of a sheep within it drinks from.

1985). Illas are a source of life and productivity, during rituals they are said to be drinking the chicha and chewing the coca given in the offerings (Allen 1988, 54, 150). Miniatures are frequently used in Andean rituals either as offerings or, as in this case, to act as a channel to transfer offerings from people to the apus (Sillar 1996). I have observed about ten of these offerings being prepared in Raqchi between 1987 and 2005 and there is quite considerable variation in each family's practices. But, all offering consist of carefully preparing groups of three good coca leaves ( $k^{\prime}$ intu) and blowing the essence (sami) to a variety of entities. The naming of offering recipients starts with the house, hearth and stores, and the family members themselves both living and dead. Each field worked by the family and each bit of pasture land or path used by their animals is named, and the clay mines, roads and market places that the household members commonly visit. After this each $k^{\prime}$ intu of three coca leaves is placed onto the cloth or paper alongside a maize kernel. The maize kernels are significant as they come from one of the household's best maize cobs, stressing continuity of the seed crop which is grown in the fields of the householder's parents. Once they are prepared one bundle of coca leaves is taken into the household patio to be burnt and the other is taken to one of the household's fields to be consumed in a fire (Fig. 4). At both locations it is important to move back to the house and chew coca as soon as the fire has taken hold of the offering. Only later do people return to observe the ash and see if the complete burning of the offering shows it has been fully accepted. The household's illas are then stored away carefully until the next offering needs to be prepared.

In this ritual many of the features of Andean animism can be identified including how the blowing of coca essence (sami) and the consumption by fire (dispachu) serve to send the offering to the correct recipient. There are clear differences between the recipient of the offering (e.g. apu), the constituents of the offering (e.g. coca), material intermediaries used to help transmit the offering (e.g. illa), and the target of concern (e.g. fields, animals and households). Even though all of these possess animating energy (e.g. sami or ánimo) they occupy different positions in the social hierarchy of animate entities. The mountains and miraculous saints are somewhat distant bodies that are thought to be observant guardians concerned about the well-being of fields, crops, animal flocks, craft production and human health (Allen 1988; Sallnow 1987). While lower-order intermediaries such as illas, village crosses, and specific offering locations are in the care of households and serve to support communication and direct offerings to the great animate powers.

In order to understand these rituals we need to reconsider Frazer's (1915) concept of 'sympathetic magic', as this has a direct bearing on how the composition of the offering brings together a wide range of important locations through evocation and materials. Frazer (1915) identified 'homeopathic magic' where 
like produces like, or an effect resembles its cause (which he called the law of similarity), and 'contagious magic' where things which have once been in contact with each other continue to act on each other at a distance even though the physical contact has been severed (which he called the law of Contact or Contagion). Frazer placed both of these under the umbrella term of 'sympathetic magic', as they both assume that things act on each other at a distance through a 'secret sympathy'. Although Frazer's Victorian attitude to evolutionary progression from magic, through religion to science has been widely criticized, his analysis correctly identified widespread practices that utilized the principles of similarity and contagion and his examples also showed great variability in the specifics of their application.

These are important concepts in how people conceive materials to have a social relationship and influence that is quite distinct from their physical properties. A critical reconsideration of materiality in past societies requires a re-evaluation of Frazer's important concepts. This could be described as the 'inalienable character of things'. Whereas Weiner (1992) focused on how objects remain connected to previous human owners, even if physically separated, Frazer's concepts of similarity and contagion stress how objects are connected to other objects, places, or animate entities through their raw materials and form. The assumption that you can influence one thing based on its prior relationship to another person, place, thing or process is a primary principle of present day Andean ritual practice. The composition of many ritual offerings, including the ones prepared in Raqchi, requires the components to be brought together from a wide range of environments and contexts to influence the animate forces of the material world through their evocative form and the continuing communion with their prior source (Bolin 1998, 40-41; cf. Zedeño 2008). Thus, places and things are considered to have a similar social relatedness to those surrounding human kinship. Just as people remain connected and obliged to their biological family and to those whom they acknowledge through marriage, adoption or fictive kin relationships, so too the 'inalienable character of things' means objects continue to exert an influence on their origin or referent.

In the fifteenth and early sixteenth centuries Inka state ritual specialists prepared elaborate offerings that involved the sacrifice of carefully selected objects and sometimes animals and children. For instance capacocha offerings were prepared in Cuzco and sent to many different locations. These could include mullu (Spondulus shells from the Ecuadorian coast),

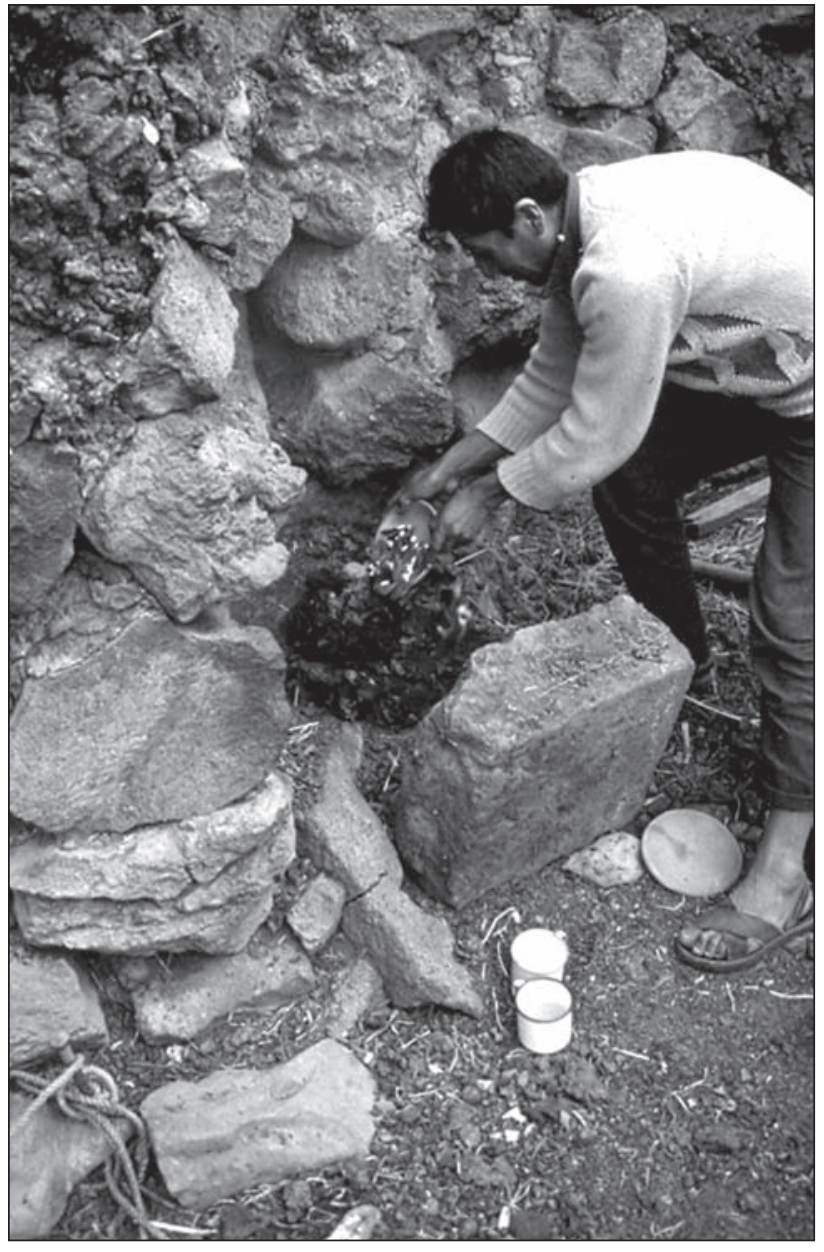

Figure 4. Raqchi, Dept. Cuzco, Peru. At the corner of a field, next to an Inca carved stone, where this household always burns their offering. The father has prepared a small animal dung fire onto which he places the offering of coca leave k'intus, maize kernels, animal fat and herbs, he then added the alcohol and sprinkled some chicha from the cups by his feet before we returned to his house while the fire consumed the offering for the apu.

coca leaves from the lowlands, cumbi (fine textiles), miniature gold, silver and shell statuettes of people and camelids, featherwork from Amazonia, highland camelids, a range of pottery vessels manufactured in diverse locations, keros (wooden drinking cups) and youthful boys and girls aged between about 5 and 15 (Cobo 1990, 154; Reinhard 1992; 1996; Bray et al. 2005; Wilson et al. 2007). Like the present-day domestic offering in Raqchi, these Inka state offerings develop relationships between disparate places through the materiality of the offering's many components (and no doubt the prayers and evocations: Bray et al. 2005, $86-7,95-8)$. 
Although the elaborate ceremonies of the Inka in Cuzco were reported to the chroniclers, it is important to consider that the mountain-top sacrifice could not have been witnessed by many. Like the dispachu in Raqchi, it was the huaca or the apu that were the intended observer/consumer. Rather than seeing these offerings as the Inka state 'physically claiming sacred sites and spaces' (Bray, this issue), I believe that Inka offerings are better understood as an act of communication with the sentient power of these places. Like the maize kernels, coca leaves, and illas used in Raqchi, the children, food vessels and metal figurines used in the Inka capacochas each had complex biographies that made 'inalienable connections' to their places of origin or manufacture and symbolic referents through their form and decoration. The act of sacrifice was intended to make these source locations and referents into links of reciprocity with the animate mountain, these were no doubt further directed through the prayers and rituals that went into preparing the offering. The composition of these offerings aimed to bind the animate mountain or huaca recipients into social obligations that requested the power and fecundity of the mountain to contribute to the many parts of the Empire that contributed to the offering, particularly the ritual centre of Cuzco where the offering was first prepared.

\section{Relating Andean animism to agency theory}

Our social relationship with the material world

Animism locates people as participants in the material world and demands that they take responsibility for their relationship with animals, plants, places, things and people (Ingold 2000; Bird-David 1999; Hornborg 2006). Animism does not make people fatalistic or disengaged: in fact one of the strongest components of Andean animism is a concern over moral behaviour and social responsibility to other people, as well as the animate world. Although there are spirits and dangerous non-corporeal beings in the Andean world-view, the essence of Andean animism is not in the 'spirits', it is in the social identities of material places and things which are considered to be sentient: 'for Andeans, all matter is in some sense alive, and conversely, all life has a material base' (Allen 1988, 62). Both Tylor's (1913) focus on the belief that animistic entities have a soul or a spirit, and the ethnographic focus on the rituals and offerings where animistic concerns are most clearly expressed and enacted, has had the unfortunate effect of over-exoticizing animism. Animism is an ontology which has at its core the simple philosophy that people have an inter-dependent social relation- ship with the material world. For many people in the Central Andean highlands today, rituals that focus on the apus and the saints are a more explicit expression of a continuous daily commitment to care for the fields, the animals and the household. The assumption that the material world is sentient and can be incorporated into social relationships is central to this commitment (Allen 1982; 1988; Gose 1994.).

If 'agency is located not simply within bounded human bodies but within the wider set of social relationships that make up the person' (Brück 2001, 655), then in the Andes such wider social relations would extend to include social interaction with the material world. Andean rituals are based on the concept that things that have had a prior relationship, or evoke similarities, with other places, things or people may continue to have an effective relationship with their origin or referent. In fact the human kinship and the animistic relatedness of 'sympathetic magic' are combined when stone huacas are considered to be human ancestors. This is expressed in the idea of mutual consumption where the people and the animate places and things of the Andes feed and nurture each other. This could be considered in relation to Robb's (2004) 'extended artefacts' and Gell's (1998) 'distributed persons' where the identity of people and meaning of things are co-constructed, and yet each person, each object and each place have distinct histories with particular networks of relationships.

\section{Animism as an essential aspect of human engagement} with the material world?

Almost all theoretical discussions of material agency focus on human-made-artefacts and technology, but Andean animism primarily focuses on places and natural features, although some artefacts such as illas, carved huacas and buildings are also powerful entities. This focus on the power of the natural environment partly reflects rural Andean communities' fundamental concern with agriculture and animal herding. Although many Andean people see everything as potentially having animate qualities, they are selective in which features they choose to engage with in active rituals. Everyone invests some things and places with more emotional engagement than others and these items, or locations, tend to be strong reference points for our personal and cultural identity (e.g. cars, homes, flags or Kula necklaces). It is the personal relationship and communal commitment that we invest in specific items that gives them their agency. The idea that some places and things have greater agency than others is similar to the variability of human agency (where a president's agency is greater than a slave's), the social 
agency of things, just like that of people, depends on their context and the network of relationships that they are involved in.

Hornborg (2006) argues that in practice we all have animistic tendencies. While we may take a modernist detachment in relation to construction or engineering, we are content to adopt a more relational and morally driven attitude to our homes and personal life. 'We probably all have reassured spaces in our lives where we are practising animists, in the sense that engagement and "relatedness" take precedence over detached observation' (Hornborg 2006, 23). Unlike the rigours of written logic, in practice we can accommodate diverse perceptions and explanations, and choose to highlight different aspects at different times. Many of us combine an acceptance of objective scientific explanations, religious convictions, the rituals of Father Christmas and belief in the "power of love', without needing to fully reconcile them. Similarly the people of the Andean highlands farm, herd and mine, they discuss pollution and global warming, go to Catholic churches and communicate with landscape features and ancestors. Andean construction workers provide detailed technological and material explanations for their building work as well as preparing offerings for the strength and wellbeing of their buildings. In practice we neither have a purely animistic belief in the social agency of things nor a purely objective understanding of our physical exploitation of material properties. Part of the creativity of our social engagement in the world is precisely the ability to move between, or combine, our technical manipulation of materials and our social relationship with them as emotive things. This facilitates our ability to creatively combine diverse components to make material culture that is both functional and meaningful, and it also gives many objects a powerful secondary agency to move beyond any physical function and engage our attention at an emotional level.

Humans differentiated themselves from other animals partly through developing their wider sociality (Mead 1932). This was accomplished through their (our) social engagement with the material world, including the relational view of the 'inalienable character of things', which permits places and things to carry identities and meanings. It is likely that some of the earliest ways in which artefacts and materials were used to communicate meaning was in their use to direct messages at non-human entities. This is expressed in the common interpretation that Upper Palaeolithic rock art was created as a form of sympathetic magic during hunting rituals (Lewis-Williams \& Clottes 1998). I suspect that the ability to give things social meaning, and the idea of symbolic storage (Donald 1991; Renfrew 2004), would not have been possible without the ambiguous sociality that allows people to have social relationships with things while at the same time objectivizing them as manipulable material resources.

\section{Human agency in the Andes}

As discussed above, Andean animism considers the material world to be sentient and critically responsive to human actions. What I am less clear about is if, or how, the distinction between the agency of people and the agency of things would, or could, be articulated by Andean people. Perhaps this is partly expressed in the alma/ánimo distinction. While many entities have the vitalizing social energy of ánimo, only people possess a soul (alma). While the concept of the human soul may have been introduced into the Andes as a part of the conversion to Christianity, this distinction does seem to express a fairly fundamental characterization of what it is to be human. Unlike ánimo, the alma continues to exist as it journeys after death, revisiting their former communities and fields at the start of each rainy season and eventually the almas join a community of the dead who undertake essential complementary agricultural work to that of the living (Allen 1982; Harris 1982). While the animate powers of the mountains, fields and saints are largely described as guardians who watch and react to what people do, it is people who strive to work on the land and make offerings. Indeed the core duty of a responsible person in the Andes is to care for animals, fields, and family through their labour and social exchange. In the first section of this article I expressed my opinion that human agency is the creative ability to imagine aims and enact these through the human body and its sociality. But, if Andean people were to talk of 'human agency', I think they would stress how it is located in the reciprocity between people, places and things and the hard physical work that people undertake to maintain these relationships. If human agency is considered to be distinct from that of other forces in the Andean world it is because of the energy people bring to working cooperatively with animals, fields and mines, and the social relationships that they develop not just with other people but also with the material world.

\section{Acknowledgments}

I would like to thank Tamara Bray and Ben Alberti for inviting me to participate in a stimulating WAC session. Andrew Gardner, Sarah Byrne, Cesar Astuhuaman, and stu- 
dents in the UCL Masters in Artefact Studies seminar were influential in discussing some of these ideas with me. Diura Thoden van Velsen, Tamara Bray, Andrew Gardner and Ben Alberti helpfully critiqued and edited previous versions of this article which allowed me to develop and clarify some points. Henry Stobart and Catherine Allen kindly shared with me some of their understanding of Andean animism and possible distinctions between alma and ánimo. I would particularly like to thank the patient people of Raqchi and Pumpuri who generously included me in their activities and tried to educate me into a better understanding of the world. Any errors in this article remain my responsibility, and reflect the fact that my education is ongoing.

\section{Bill Sillar \\ Insitute of Archaeology \\ University College London 31-34 Gordon Square \\ London \\ WC1H OPY \\ UK \\ Email:b.sillar@ucl.ac.uk}

\section{References}

Abercrombie, T.A., 1998. Pathways of Memory and Power: Ethnography and History among an Andean People. Madison (WI): University of Wisconsin Press.

Allen, C.J., 1988. The Hold Life Has: Coca and Cultural Identity in an Andean Community. Washington (DC): Smithsonian Institution Press.

Allen, C.J., 1982. Body and soul in Quechua thought. Journal of Latin American Lore 8(2), 179-96.

Allen, C.J., n.d. The Sadness of Jars: Separation and Rectification in Andean Understandings of Death. Unpublished manuscript.

Appadurai, A., 1986. The Social Life of Things: Commodities in Cultural Perpective. Cambridge: Cambridge University Press.

Bastien, J.W., 1978. Mountain of the Condor: Metaphor and Ritual in an Andean Ayllu. (American Ethnological Society Monograph 64.) St Paul (MN): West Publishing.

Bird-David, N., 1999. Animism revisited: personhood, environment, and relational epistemology. Current Anthropology 40, 67-91.

Bolin, I., 1998. Rituals of Respect: the Secret of Survival in the High Peruvian Andes. Austin (TX): University of Texas Press.

Bourdieu, P., 1977. Outline of a Theory of Practice. Cambridge: Cambridge University Press.

Bray, T.L., L.D. Minc, M.C. Ceruti, J.A. Chávez, R. Perea \& J. Reinhard, 2005. A compositional analysis of pottery vessels associated with the Inca ritual of capacocha. Journal of Anthropological Archaeology 24, 82-100.

Brück, J., 2001. Monuments, power and personhood in the British Neolithic. Journal of the Royal Anthropological Institute 7, 649-67.

Cobo, B., 1990. Inca Religion and Customs (1653), translated by
R. Hamilton. Austin (TX): University of Texas Press. Descola, P., 1994. In the Society of Nature: a Native Ecology in Amazonia. Cambridge: Cambridge University Press.

Dobres, M.-A. \& J.E. Robb (eds.), 2000. Agency in Archaeology. London: Routledge.

Donald, M., 1991. The Origins of the Modern Mind. Cambridge (MA): Harvard University Press.

Emirbayer, M. \& A. Mische, 1998. What is agency? American Journal of Sociology 103(4), 962-1023.

Flores-Ochoa, J.A., 1979. Pastoralists of the Andes, translated by R. Bolton. Philadelphia (PA): Institute for the Study of Human Issues.

Frazer, J.G., 1915. The Golden Bough: a Study in Magic and Religion. 3rd edition. London: Macmillan.

Gardner, A., 2007. Agency, in Handbook of Archaeological Theories, eds. R.A. Bentley, H.D.G. Maschner \& C. Chippindale. Lanham (MD): Altamira, 95-108.

Gell, A., 1998. Art and Agency: an Anthropological Theory. Oxford: Clarendon Press.

Giddens, A., 1984. The Constitution of Society. Cambridge: Polity Press.

Gosden, C., 2005. What do objects want? Journal of Archaeological Method and Theory 12(3), 193-211.

Gose, P., 1986. Sacrifice and the commodity form in the Andes. Man 21, 296-310.

Gose, P., 1994. Deathly Waters and Hungry Mountains: Agrarian Ritual and Class Formation in an Andean Town. Toronto: University of Toronto Press.

Gose, P., 2006. Mountains historicized: ancestors and landscape in the colonial Andes, in Kay Pacha: Cultivating Earth and Water in the Andes, ed. P. Dransart. (British Archaeological Reports 1478.) Oxford: BAR.

Guamán Poma de Ayala, F., 1988. El Primer Nueva Crónica y Buen Gobierno (1584-1615). México: Siglo Veintiuno Editores.

Harvey, G., 2005. Animism: Respecting the Living World. New York (NY): Columbia University Press.

Harris, O., 1982. The dead and the devils among the Bolivian Laymi, in Death and the Regeneration of Life, eds. M. Bloch \& J. Parry. Cambridge: Cambridge University Press, 45-73.

Hornborg, A., 2006. Animism, fetishism, and objectivism as strategies for knowing (or not knowing) the world. Ethnos 71(1), 21-32.

Ingold, T., 2000. The Perception of the Environment: Essays in Livelihood, Dwelling and Skill. London: Routledge.

Ingold, T., 2006. Rethinking the animate, re-animating thought. Ethnos 71(1), 9-20.

Isbell, B.J., 1985. To Defend Ourselves: Ecology and Ritual in an Andean Village. Prospect Heights (IL): Waveland Press.

Jones, A., 2007. Memory and Material Culture. Cambridge: Cambridge University Press.

Latour, B., 1993. We Have Never Been Modern. Cambridge (MA): Harvard University Press.

Laurencich-Minelli, L., 1991. El trabajo como forma de culto estatal en el Imperio Inca, in El Culto Estatal del Imperio Inca, ed. M.S. Ziólkowski. (Memorias del $46^{\circ}$ Congreso Internacional de Americanistas Symposio 
ARC-2 Amsterdam 1988.) Place??: Centro de Estudios Latinoameicanos, Universidad de Varsovia, 55-8.

Lewis-Williams, D.J. \& J. Clottes, 1998. The Shamans of Prehistory: Trance Magic and the Painted Caves. New York (NY): Abrams.

Marett, R., 1914. The Threshold of Religion. London: Methuen.

Mauss M., 1990. The Gift: the Form and Reason for Exchange in Archaic Societies, translated by W.D. Hall. London: Routledge.

Mead, G.H., 1932. The Philosophy of the Present. Chicago (IL): Open Court Publishing.

Mead, G.H., 1934. Mind, Self and Society. Chicago (IL): University of Chicago Press.

Mead, G.H., 1938. The Philosophy of the Act. Chicago (IL): University of Chicago Press.

Merleau-Ponty, M., 2002. The World of Perception, translated by O. Davis. London: Routledge.

Mithen, S., 2001. Archaeological theory and theories of cognitive evolution record, in Archaeological Theory Today, ed. I. Hodder. Cambridge: Polity Press, 98-121.

Reinhard, J., 1992. Sacred peaks of the Andes. National Geographic Magazine 181(3), 84-111.

Reinhard, J., 1996. Peru's ice maiden. National Geographic Magazine 189(6), 62-81.

Renfrew, C., 2004. Towards a theory of material engagement, in Rethinking Materiality: the Engagement of Mind with the Material World, eds. E. DeMarrais, C. Gosden \& C. Renfrew. (McDonald Institute Monographs.) Cambridge: McDonald Institute of Archaeological Research, 23-31.

Robb, J.E., 2005. The extended artefact and the monumental economy, in Rethinking Materiality: the Engagement of Mind with the Material World, eds. E. DeMarrais, C. Gosden \& C. Renfrew. (McDonald Institute Monographs.) Cambridge: McDonald Institute of Archaeological Research, 131-9.

Sallnow, M.J., 1987. Pilgrims of the Andes: Regional Cults in Cusco. Washington (DC): Smithsonian Institution Press.

Sillar, B., 1996. Playing with God: cultural perception of children, play and miniatures in the Andes. Archaeological Review from Cambridge 13(2), 47-63.

Sillar, B., 2000. Shaping Culture: Making Pots and Constructing Households. An Ethnoarchaeological Study of Pottery Production, Trade and Use in the Andes. (British Archaeological Reports International Series 883.) Oxford: BAR.
Sillar, B., 2004. Acts of God and active material culture: agency and commitment in the Andes, in Agency and Archaeology, ed. A. Gardner. London: UCL Press, 153-209.

Sterner, J., 1989. Who is signalling whom? ceramic style, ethnicity and taphonomy among the Sirak Bulahay. Antiquity 63, 451-9.

Stobart, H., 1996. Tara and q'iwa: worlds of sound and meaning, in Cosmología y Música en los Andes, ed. M. Baumann. Frankfurt \& Madrid: Vervuert \& Iberoamericana, 67-82.

Stobart, H., 2006. Music and the Poetics of Production in the Bolivian Andes SOAS Musicology Series. Aldershot: Ashgate.

Strauss, C., 2007. Blaming for Columbine: conceptions of agency in the contemporary United States. Cultural Anthropology 48(6), 807-32.

Tylor, E.B., 1913. Primitive Culture: Researches into the Development of Mythology, Philosophy, Religion, Language, Art and Custom. 5th edition. London: Murray.

Weiner, A., 1992. Inalienable Possessions: the Paradox of Keeping While Giving. Berkeley (CA): University of California Press.

Weismantel, M., 1988. Food, Gender and Poverty in the Ecuadorian Andes. Philadelphia (PA): University of Pennsylvania Press.

Wilson, A.S., T. Taylor, M.C. Ceruti et al., 2007. Stable isotope and DNA evidence for ritual sequences in Inca child sacrifice. Proceedings of the National Academy of Sciences of the USA 104, 16,456-61.

Zedeño, M.N., 2008. Bundled worlds: the role and interactions of complex objects from the North American Plains. Journal of Archaeological Method and Theory 15, 362-78.

\section{Author biography (c. 50 words)}


